\section{Chiz L., Khotyeyeva $\mathbf{N}$., Zadorozhna $\mathbf{N}$.}

\title{
THE BASIS OF PORT ENTERPRISE FINANCIAL STRATEGY
}

Об’єктом дослідження є процес формування фінансової стратегї̈ портового підприємства. Предметом роботи є деякі аспекти механізму вибору фінансової стратегії портового підприємства, а саме методичний підхід до вибору фінансової стратегї. Одним з найбільи проблемних місць є складові механізму формування стратегії, зважаючи на те, що у теорії і практиці фінансового управління використовуються різні методики, кожна з котрих має свої недоліки та переваги. Ці методики включають методи матричного моделювання, стратегічного аналізу сильних і слабких сторін діяльності, фінансового аналізу. Використання тих чи інших методичних підходів до вибору фінансової стратегї повинне комплексно представити процедуру вибору альтернативних напрямків стратегічного розвитку.

В ході дослідження був застосований матричий підхід до вибору виду фінансової стратегї портового підприємства, що потребує визначення послідовності окремих етапів формування відповідних матриць. У сучасній науковій літературі процесу побудови таких матриць стратегічного вибору приділяється недостатньо уваги. За єдиним параметральним складом матриці не може здійснюватись вибір всіх без винятку видів стратегій підприємства. На першому етапі можна скористатись систематизацією видів фінансової стратегї портових підприємств. Однак не всі види стратегій потребують матричного вибору.

У процесі дослідження розглянуто умови формування фінансової стратегї підприємства та компетенцї фінансової стратегї сучасного портового підприємства. А також наведено приклад методичного підходу вибору фінансової стратегї портового підприємства, а саме сформована основна та допоміжна матриия вибору виду фінансової стратегї першого класу. Визначено систему факторів, що впливають на вибір фiнансової стратегї цього класу, та відбувається їх ранжування за ступенем впливу. За кожним класом стратегій були відібрані основні фактори за критерієм рівня їх впливу, діагностуванні на попередньому етапі. Визначено глибину диференціації за кожним із обраних факторів, яка може коливатися у значному діапазоні.

Обрана у роботі методика дозволяє більш чітко уявити процес вибору фінансової стратегії окремого підприємства.

Ключові слова: фінансова стратегія, матриия вибору стратегї, портове підприємство, фінансові ризики.

Received date: 11.06.2019

Accepted date: 27.06 .2019

Published date: 30.10 .2019
Copyright (C) 2019, Chiz L., Khotyeyeva N., Zadorozhna N. This is an open access article under the CC BY license (http://creativecommons.org/licenses/by/4.0)

\section{Introduction}

Successful commercial activity of an enterprise provides for rational financial management, the basis of which is a scientifically based methodology for predicting the directions of its development. The strategic aspect forms the competitive advantages of the enterprise. High competitiveness, solvency, financial stability and profitability of the enterprise can be ensured through competent financial policy. This, in turn, involves the management of assets and liabilities, investments, expenses, working capital, profit.

Ensuring the effectiveness of strategic planning requires the development of quality strategic planning tools. One of these tools is the correct and appropriate choice of the financial strategy of the enterprise, which is an important and inalienable step in the process of forming a common strategy.

The need to improve the organizational and methodological approaches of the process of financial forecasting of enterprises of the marine industry, especially with the presence of various business processes, is an urgent task that determined the choice of the topic of work.

\section{The object of research and its technological audit}

The object of research is the process of financial planning of enterprises, namely the choice of financial strategy of the enterprise.

Formation of a financial strategy involves taking into account a large number of different factors. To select a financial strategy that would ensure an effective result of the enterprise, it is necessary first of all to determine the possible types and directions of its development.

In order to implement an effective process of financial planning, it is necessary to take into account competencies and influence factors. The methodology of choosing a strategy is also a problematic aspect.

\section{The aim and objectives of research}

The aim of research is development of an example of a methodological approach for choosing the financial strategy of a port enterprise. 
To achieve the aim of research, the following objectives are identified:

1. To consider the competencies of the financial strategy regarding industry-specific features of a modern port enterprise.

2. Consider a methodological approach to choosing a financial strategy for a port enterprise.

\section{Research of existing solutions of the problem}

The financial strategy is associated with the creation of corporate value, as well as how it affects the increase in the well-being of shareholders by creating shareholder value corresponding to the levels of perceived risk and income required by investors [1].

The authors of [2], in the process of reviewing corporate finance management, consider certain areas, focused on financial policy. And in [3] it is shown that the financial strategy indicates the direction of development of the organization in the future, acts as the basis for choosing an alternative, which leads to the nature and organization of financial relations. In this case, the emphasis is on the need to develop alternative strategies. But questions remain - what specific financial relations and between which financial structures are in mind.

The financial strategy of the enterprise quite often [4] is attributed to functional strategies and is considered from the perspective of providing financial resources, and the management of financial activities is completely different. Thus, the financial strategy includes a profit distribution strategy, investment strategy, financing strategy and legal relations strategy. Let's believe that such a definition significantly expands the scope of the financial strategy and is unjustified. But at the same time, the question of the relationship remains unresolved, how and due to low what indicators this is happening.

According to the authors of [5], the concept of strategic management reflects the policy of the enterprise (including finance), presented in the system of principles and main goals of its activities. As well as the nature of the relationship between the subject and the control object, the mechanism of interaction between the elements of the economic and organizational structure, and the forms and methods of their adaptation to the changing conditions of the macroenvironment. However, the authors of this work do not fully reveal the role and essence of strategic financial management.

In [6], a financial strategy is considered as a process that brings external sources of financial resources into line with the strategies of corporate formation, expansion and development. But the question of the relationship remains unresolved, how and due to low what indicators this happens.

The authors of [7] emphasize that financial forecasting as an essential element of planning is the basis for budgeting and assessing future financial needs. Let's believe that such a definition limits the scope of a financial strategy.

Also, an incomplete definition of the concept of «financial strategy» is provided in [8]. A financial strategy can be defined as the science of managing assets and liabilities to achieve its intended purpose.

A more practical definition of strategy [9] is that a financial strategy allows to evaluate your financial needs and resources necessary to maintain and achieve goals, as well as to achieve the organization's overarching goal. And also plan further growth to ensure the success and sustainability of the business.
One can't disagree with a more detailed list of specific tasks, the implementation of which will achieve the above goals [10]. So, in [1], a financial strategy consists in making decisions related to:

- business financing;

- decisions on the structure of capital, as well as on what profit should be paid in the form of interest or dividends and what amount should be kept for investments in new projects;

- choice of the most suitable type of loan;

- financial risk management.

The authors of [11] show that a financial strategy has two components:

1) collection of funds necessary for the organization in the most appropriate way;

2) management of the use of these funds in the organization, including the decision to reinvest or distribute any funds that are subsequently generated.

The authors of $[2,3]$ give too general a definition of financial strategy, presenting it as a long-term course of financial policy, designed for the future, which involves solving large-scale tasks of the enterprise. But from the point of view of practical implementation, a more specific understanding of the financial strategy is necessary [4] the financial strategy provides:

- formation of long-term financial goals;

- choice of the most effective ways to achieve adequate adjustment of the directions of formation and use of financial resources when changing environmental conditions.

This statement should emphasize an important point the need to take into account environmental factors that carry potential threats.

If the concept of «financial resources» is revealed, then in fact the financial strategy comes down to the development of measures for the efficient use of own and attraction of external financial resources to achieve strategic competitive advantage [12].

It is impossible to disagree with the fact that the financial strategy should take into account the specifics of the industry, and its purpose is to ensure appropriate profitability, solvency, financial stability and financial stability of the enterprise [13].

Thus, the new paradigm of substantiation of alternative options for a financial strategy should take into account the industry specifics of the enterprise's functioning, the uncertainty of the external environment, the presence of potential threats, and the ability to quickly respond to changing environmental conditions.

The main content of the long-term financial behavior of the enterprise is not so much in creating conditions for supporting the clear implementation of the tasks envisaged, but in the ability to quickly respond to changing operating conditions. This will ensure appropriate adjustment of tasks to address priority issues of the adequacy and effectiveness of the use of financial resources, in specific conditions of time and place.

\section{Methods of research}

During the execution of the work, general scientific and special research methods are applied:

- analysis and synthesis - for preliminary analysis with the formation of the problem, the definition of goals, the definition of assumptions and risks; 
- generalization - for identification of the shortcomings of the methodological approaches of choosing a financial strategy;

- abstract-logical - for theoretical generalization and formulation of conclusions.

\section{Research results}

When developing current and strategic management decisions, company leaders are aimed at finding ways to increase the enterprise's competitiveness by introducing measures to increase production, sales, quality of products, services, and reduce costs. But at the same time, they often do not pay attention to the «price» of the proposed solutions, that is, their effectiveness.

In addition, many entrepreneurs underestimate the importance of financial strategies, paying attention to production strategies. This saves them from searching for additional reserves to strengthen business positions, complicates the search for investors who are interested in long-term and stable cooperation.

However, expanding the rights of enterprises in the direction of managing financial resources, increasing their responsibility for the results of their activities and related problems, require the creation of an effective management system for this important type of resources. Such a system is the financial strategy of the enterprise.

A sound financial strategy should be an important part of the overall development strategy of the enterprise and realize its goals, allows to choose the most effective ways to achieve them through the rational formation and use of financial resources.

A financial strategy includes methods and practices for the formation of financial resources, their planning, optimization of fixed and current assets, profit generation and distribution, cash settlements and investment policies and, as a result, ensuring the financial stability of an enterprise [10, 14].

The listed goals of the financial strategy must obey the general strategy of economic development of the enterprise and contribute to maximizing profit and its market value. The optimal ratio of own and borrowed capital allows to minimize the total cost of capital, at the same time provide yourself with financial resources at an affordable price and maintain sufficient financial stability.

An effective financial strategy should take into account risks, the needs of financing a business plan, the financial goals of the enterprise, and market conditions for managing it.

Uncertainty of the economy and the instability of the development of financial markets, high risks of financial instruments, the interdependence of individual economic entities on the dynamics of the world market, the composition of the elements of the financial strategy should be formed.

The existing scientific sources highlight the dominant areas of financial development of the enterprise:

- a strategy for the formation of financial resources, the main task of which is creation of the potential of the financial resources of the enterprise, sufficient to meet the needs associated with its development;

- an investment strategy, the implementation of which allows to rationally use the financial resources of the enterprise, to correctly distribute them depending on the directions and forms of investment, taking into account the criteria for the ratio of risk and profitability;
- a strategy to ensure the financial security of the enterprise allows to ensure the financial stability of the enterprise in the process of strategic development; - a strategy to improve the quality of financial management of the enterprise in a strategic perspective [4]. Thus, the economic behavior of an enterprise is determined, first of all, by the choice of sources of financing its activities. Hence, a financial strategy must meet the following criteria:

- when choosing sources of financing, take into account factors of the internal financial environment that are easier to predict;

- take into account factors of the external financial environment that can be predicted with a certain degree of risk;

- the financial strategy should justify the choice of the ratio of sources of financing;

- take into account the financial risks associated with the choice of a particular source of financing.

The strategic potential of the enterprise includes various resources and financial opportunities, technologies, equipment, products (services), the whole range of global opportunities. Under these conditions, the traditional analysis of the environment, competitors, predicting its changes and the dynamics of the situation and based on the data obtained to extract the commercial effect of the use of opportunities finally loses its relevance. Therefore, increasingly in search of a competitive advantage, organizations turn their gaze inward, trying to identify in themselves those abilities around which it will be possible to build a business space [14].

Models of such analysis and planning have been developed by the school of resources, abilities and competencies for over 10 years. The company does not attach importance to the competencies that determine its place in the competition, exposes itself to risk.

Competence (lat. competentia - coordination, combination) is a set of objects of competence, tasks, powers, rights and obligations of an official or state or public body, are determined by the Constitution. Competence depends on the tasks that are assigned to an official or a state or public body, the type of body in the mechanism of the state, as well as relationships with other bodies [15].

The competencies of the financial strategy are shown in Fig. 1.

The composition of each competency should take into account the industry specifics of port activities:

- variety of services for the transshipment of goods;

- instability and unevenness of cargo flows of the seaports

of Ukraine and their complex organizational structure;

- dependence on unpredictable negative changes at

other transport enterprises, actions of cargo owners, port administrations, political factors.

The financial strategy should correspond to the required level of entrepreneurial (business) risk, financing needs, determine the financial goals of the enterprise, dividend policy, taking into account market conditions.

The financial strategy of the enterprise should be aimed at achieving five goals (Fig. 2).

The financial strategy characterizes the various relations of the enterprise in the production, credit, investment and financial sectors. It determines the behavior of the enterprise in the market, the formation of its market position in accordance with the state, the use of financial resources, as well as monetary instruments. 


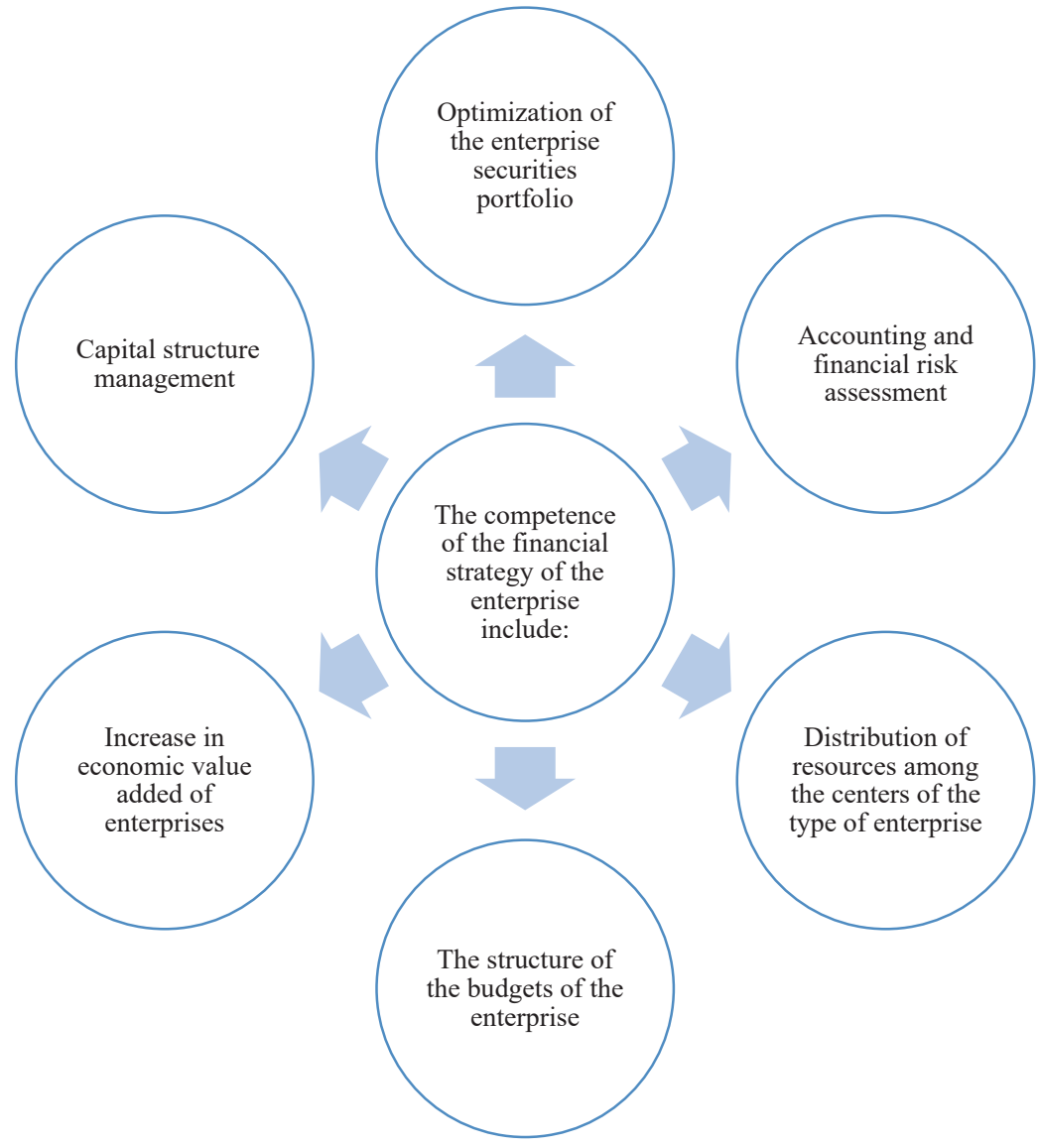

Fig. 1. Competence of financial strategy

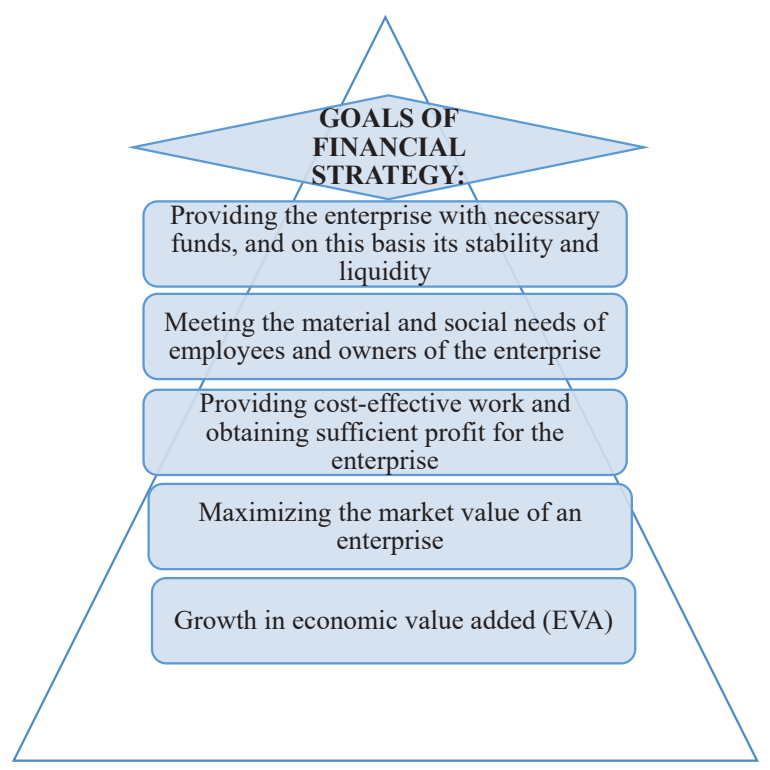

Fig. 2. The goals of the financial strategy

A financial strategy is primarily focused on the long term or solving a key priority task in a specific period of time.

The most important task is correctly determination of the strategic parameters of a financial strategy. These include:

1. Financial determinants of the overall process of enterprise development:

- the cost of acquisition and use of capital;

- tariffs for port services;
- level of production costs under the development program;

- level of wages and the volume of the wage fund;

- indicators characterizing the internal capabilities of the enterprise - the company's income, profit, depreciation, expected income from investment projects and the like.

2. The financial structure of the company:

- type of financing;

- the cost of enterprise resources;

- need for funds;

- risks of various types of financing, including the risk of bankruptcy.

3. Forms of raising funds.

4. Methods of placing funds and management features.

5. Financial mechanisms and instruments (financial mechanisms for adapting the environment, financial market instruments, in-house financial instruments).

Activities for the development and implementation of the financial strategy of the enterprise are a kind of management activity, which is a set of actions in the financial management system of the enterprise.

The theory and practice of financial management uses methods of matrix modeling, strategic analysis of the strengths and weaknesses of activities, financial analysis.

Without diminishing the significance and the possibility of using certain methodological approaches to choosing a financial strategy, it should be noted that their use does not allow a comprehensive presentation of the procedure for choosing alternatives. Since they do not pay attention to the following important aspects:

1) formation of an analytical basis for the parameters of the choice of financial strategy based on the strategic diagnostic procedure;

2) optimization of the procedure for choosing an alternative to a financial strategy;

3) rationing and justification of limitations of target vectors of strategic alternatives depending on the state of financial equilibrium and changes in financial and economic stability;

4) modeling the behavior of the net assets and liabilities of the enterprise with various strategic alternatives.

Imagine the process of optimizing the choice of alternatives to a financial strategy in the form of a structural logical diagram in Fig. 3.

In [13], it is stated that the initial position of the choice of financial strategy will be determined by the concept and principles of the formation of the mechanism of financial strategy. The process of choosing an alternative to a financial strategy is based on a systematic and scenariobased approaches, the use of which makes it possible to present, on the one hand, the continuity of the selection procedure, and on the other hand, the use of an integral criterion of the potential for financial and economic stability, which will justify the optimal choice. The main attention is paid to the choice of financial strategy from 
the achieved financial condition of the enterprise to the prospects for its sustainable development based on the construction of scenario options.
The «matrix method» is considered more promising [13]; it is possible to consider it as an approach to choosing a financial strategy for a port enterprise.

As noted in [16], «the matrix method implements the choice of the best solution from a set of alternatives».

So, the «matrix method» in the system of modern methodology to ensure the selection of the type of any (including financial) strategy of the enterprise has a priority role.

Application of a matrix approach to choosing the type of financial strategy of a port enterprise requires determining the sequence of the individual stages of formation of the corresponding matrices. In the modern scientific literature, the process of constructing such matrices of strategic choice is not given enough attention.

Fig. 3. The process of optimizing the choice of alternatives to a financial strategy
The feedback information allows to compare the result of the implementation of the financial strategy with the goals of the strategy at the input and determine the deviations of the real vector of development of the system from the ideal. It is the deviation of the actual parameters from the set that makes up the essence of the problem. Since management is a cycle of solving a problem, and financial decisions, according to the theory of decision making, are unprogrammed, the process of solving problems is endless.

The formulation of the problem and its understanding is the starting point for choosing a financial strategy and strategic goals.

When choosing strategic goals, the requirements of efficiency should be observed, that is, achieving the main goal of the financial strategy - maximizing the value of the enterprise. Moreover, the financial strategy should be developed in such a way that the implementation of one strategic goal does not affect another [4].

It is advisable to consider the main methodological approaches to the selection of types of enterprise strategies. One of these approaches is «pushing away from opportunities», that is, it is based only on the possibility of developing an enterprise in a strategic period.

Quite often, to propose a type of strategy at any level, scientists propose using the «crooked experience» methodological approach.
The main attention of scientists is focused only on one of the stages of this process - on the determination and selection of factors that should be the basis for the formation of matrix parameters that model the choice of the type of strategy from the provided alternatives. Of course, this stage is central and most important in the process of forming the corresponding matrices, but far from the only one.

Before considering the system of factors that should be the basis for the formation of matrices, it should be clearly defined that a matrix system is assigned to select all types of enterprise strategies. Indeed, to select the type of enterprise strategy, specific factors are needed that should be the basis for the formation of matrices. In other words, according to a single parameter composition of the matrix, the selection of all types of enterprise strategies, without exception, can't be made.

The author of [17] proposes the following sequence of the process of constructing matrices for choosing the types of financial strategies of a particular type of enterprises in the context of its individual stages (Fig. 4).

It is advisable to consider in detail the methodological approaches to the formation of such matrices in stages.

At the first stage, it is possible to use the classification of types of financial strategies of port enterprises, which are given in Table 1. However, not all types of strategies will require matrix choices.

Stage 1. Determination of a specific class of financial strategies with all options for
their types

Fig. 4. The scheme for constructing the process of forming matrices for choosing the type of financial strategy [17] 
The system of differentiation of individual factors for constructing matrices for choosing the types of financial strategies of port enterprises

\begin{tabular}{|c|c|c|c|}
\hline \multirow{2}{*}{ Key factors } & \multicolumn{3}{|c|}{ Differentiation of factors according to relevant characteristics } \\
\hline & First & Second & Third \\
\hline $\begin{array}{l}\text { Type of basic corporate strategy of an enterprise } \\
\text { or its business units }\end{array}$ & Rapid growth strategy & $\begin{array}{l}\text { Moderate growth or stabilization } \\
\text { strategy }\end{array}$ & Strategy «curtailment of activities» \\
\hline $\begin{array}{l}\text { The vector of economic activity of the enterprise } \\
\text { in the strategic period }\end{array}$ & Differentiation of activities & Focusing on a specific activity & Rejection of less profitable activities \\
\hline $\begin{array}{l}\text { Description of the key competencies of the } \\
\text { enterprise in the field of financial activity }\end{array}$ & $\begin{array}{l}\text { Increase the economic added value } \\
\text { of the enterprise }\end{array}$ & $\begin{array}{l}\text { The most important competencies in } \\
\text { the field of both external and internal } \\
\text { environment of the enterprise }\end{array}$ & $\begin{array}{l}\text { The most important competencies } \\
\text { mainly in the field of the internal } \\
\text { environment of the enterprise }\end{array}$ \\
\hline $\begin{array}{l}\text { The results of the diagnosis of factors of the } \\
\text { external financial environment of the enterprise }\end{array}$ & $\begin{array}{l}\text { Availability of development support } \\
\text { opportunities }\end{array}$ & $\begin{array}{l}\text { Lack of development support op- } \\
\text { portunities }\end{array}$ & Development threats \\
\hline $\begin{array}{l}\text { The results of the diagnosis of factors of the } \\
\text { internal financial environment of the enterprise }\end{array}$ & $\begin{array}{l}\text { Formation of own sources of forma- } \\
\text { tion of resources for development }\end{array}$ & Optimal capital structure & Weak internal position \\
\hline Enterprise life cycle stage & $\begin{array}{l}\text { Stages from birth to youth of the } \\
\text { enterprise }\end{array}$ & Enterprise maturity stage & Stage of aging \\
\hline
\end{tabular}

At the second stage, a system of factors is determined that affect the choice of the financial strategy of this class, and they are ranked by degree of influence

At the third stage, for each class of strategies, the main factors should be selected according to the criterion of their influence level, diagnostics at the previous stage.

Thus, the use of a matrix approach to the selection of types of financial strategies for port enterprises and the construction of appropriate strategic choice matrices for all classes of strategies should be based on a combination of the following main factors:

1) the type of basic corporate strategy or, accordingly, the basic strategy of business units;

2) the vector of the dynamics of economic activity of the enterprise in the strategic period;

3 ) the predicted rate of dynamics of the main activities of the enterprise in the strategic period;

4) the nature of the key competencies of the enterprise in the field of financial activity;

5) the results of the diagnosis of factors of the external financial environment;

6) the results of the diagnosis of factors of the internal financial environment;

7) the stage of the life cycle of the enterprise.

At the fourth stage (differentiation of the values of the parameters of the selection matrices by their quantitative or qualitative characteristics), first of all, it is necessary to determine the depth of differentiation for each of the selected factors, which can fluctuate in a significant range. Some researchers for each matrix factor establish only two versions of their characteristics [5, 11, 17].

At the fifth stage, in the process of choosing the shape of the matrices, it is most consistent with the particularities of choosing the financial strategy of this class, it is necessary to pay attention to two main characteristics of the matrices - their shape and the number of factors (parameters) that are considered in them. In the modern scientific literature on the problems of strategic management, various forms of matrices are proposed for choosing types of strategies [18].

For the two-factor matrices that are used most often, a tabular matrix is easy to read.

At the sixth stage, when a specific matrix is developed for choosing the type of financial strategy for this class, the main task is selection of the factors that have independent influence. In addition, for each class of financial strategies, the main and auxiliary matrices should be determined by the degree of impact intensity.

Let's construct a matrix for choosing the type of financial strategy of a port enterprise (Fig. 5).

Next, let's present the matrices for choosing a strategy (Fig. 6)

General financial strategy

Factors: financial risk and availability of financial resources

Dynamics vector selection

Formation of the main matrix of the first class strategyy

Formation of an auxiliary matrix

Choosing strategy

Fig. 5. Formation of a financial strategy 


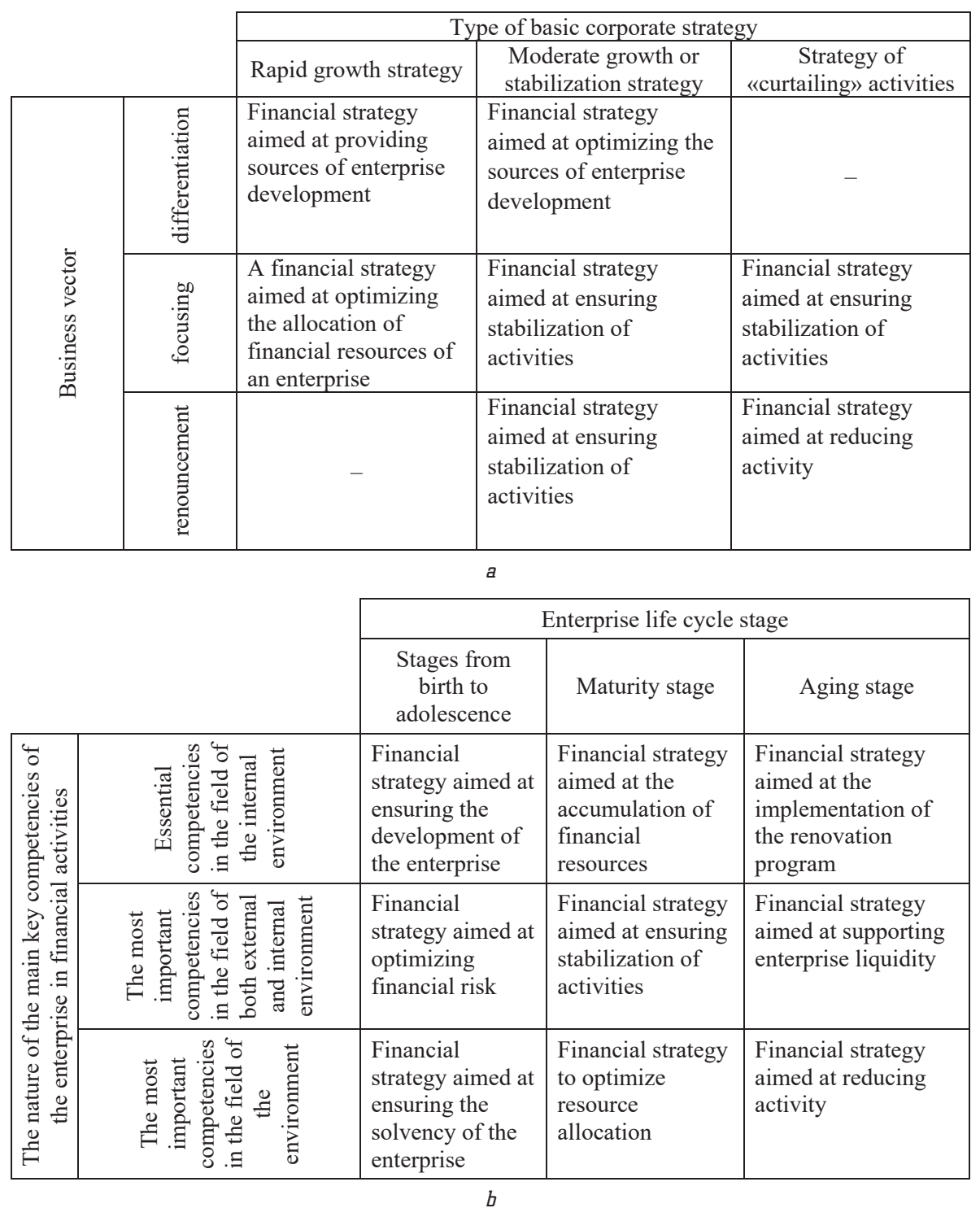

Fig. 6. Matrices for choosing the type of financial strategy aimed at supporting the corporate strategy of the port enterprise: $a$ - the main matrix for choosing the type of financial strategy of the first class; $b$ - the auxiliary matrix for choosing the type of financial strategy of the first class

Thus, the matrix in Fig. 6 allows to provide a choice of the type of financial strategy of the port enterprise in the conditions of its functioning at a particular point in time, taking into account the most relevant vectors.

\section{SWOT analysis of research results}

Strengths. The strengths of research are related to the practical aspect of financial planning. The selected methodology makes it possible to more clearly represent the process of choosing a financial strategy for a port enterprise.

Weaknesses. The weakness of the proposed approach is the limited number of factors that are taken into account in the approach.

Opportunities. It should be noted that in the future, the process of choosing a financial strategy can be supplemented with auxiliary matrices of first-class strategies, which makes it possible to improve the financial planning process.

Threats. The proposed approach is not a technology to avoid losses in general due to the influence of various kinds of risks. In particular, for the negative impact of environmental factors on the object of research.

\section{Conclusions}

1. It is established that the process of choosing a financial strategy is quite complicated, therefore, a matrix approach to choosing the type of financial strategy of a port enterprise is used to more accurately determine the type of strategy.

It is shown that it is impossible to compose a matrix that is uniform in its parameters, since it is necessary to take into account the development vector.

2. The methodological approach to the choice of the financial strategy of the port enterprise is considered. In the course of which an example is given of a methodological approach to choosing a financial strategy for a port enterprise, namely, the main and auxiliary matrix for choosing the type of financial strategy of the first class is formed. The existing matrix allows to provide a choice of the type of financial strategy of the port enterprise in the con- 
ditions of its functioning at a particular point in time, taking into account the most relevant vectors.

\section{References}

1. Davies, T., Crawford, I. (2014). Corporate Finance and Financial Strategy. Pearson Education, 976.

2. Bocharov, V. V., Leontyev, V. Ye. (2008). Korporativnyye finansy. Saint Petersburg: Piter, 592.

3. Vilkomir, A. K. (2011). Printsipy i metody finansovoy strategii predpriyatiy v usloviyakh ekonomicheskogo krizisa. Audit $i$ finansoryy analiz, 3, 15-20.

4. Pavlicek, J. (2009). Corporate Financial Strategy in SMEs. Proceedings of the World Congress on Engineering, II WCE. London, $1356-1358$

5. Thompson, A. A., Strickland, A. J., Thompson, J. (1999). Strategic Management. Ed. 11. McGraw-Hill Companies, 1088.

6. McGee, R. T. (2015). The Business Cycle. Applied Financial Macroeconomics and Investment Strategy. doi: http://doi.org/ 10.1057/9781137401809.0006

7. Shim, Ph. D., Jae, K., Siegel, Ph. D., Joel, G. (2008). Financial Management (Barron's Business Library Series). Ed. 3. Barron's Educational Series, 400.

8. Tiffin, R. (2014). Executive Finance and Strategy: How to Understand and Use Financial Information to Set Strategic Goals. Kogan Page Publishers, 344.

9. Chartered Institute of Management Accountants. Essential tools for management accountants (2013). The tools and techniques to support sustainable business success. Available at: https:// www.cgma.org/resources/tools/essential-tools/downloadabledocuments/essential-tools-for-management-accountants.pdf

10. Clarke, R. G., Wilson, B. D., Daines, R. H., Nadauld, S. D. (1988). Strategic financial management. Irwin, 241.

11. Bender, R., Ward, K. (2012). Corporate Financial Strategy. London: Routledge, 320. doi: http://doi.org/10.4324/9780080490816

12. Gudz, O. (2013) Fínansovi strategii zabezpechennya konkurentospromozhnosti pídpriêmstva. Financial space, 4 (12), 98-99.
13. Nagorna, O. (2012). Strategiya finansovogo zabezpechennya pidpriemstv komunal'nogo gospodarstva: sutnist' ta osoblivosti. Yefektiona yekonomika, 9. Available at: http://economy.nayka. com.ua/?op $=1 \& \mathrm{z}=1385 . \mathrm{htm}$

14. Peshkova, A. A. (2011). Vybor finansovoi strategii ustoichivogo razvitiia predpriiatiia. Finansovii menedzhment, 14 (56), 12-17. Available at: https://cyberleninka.ru/article/v/vyborfinansovoy-strategii-ustoychivogo-razvitiya-predpriyatiya

15. Yuridichni termini. Tlumachniy slovnik. Available at: https://pidruchniki.com/20101014/poshuk?cx=partner-pub-4735452452517403 $\% 3$ A1958805405\& $\mathrm{cof}=$ FORID $\% 3 \mathrm{~A} 10 \& \mathrm{ie}=\mathrm{UTF}-8 \& \mathrm{q}=\%$ D0 \%BA \%D0 \%BE \%D0 \%BC \%D0 \%BF \%D0 \%B5 \%D1 \%82 \%D0 \%B5 \%D0 \%BD \%D1 \%86 \%D1 \%96 \%D1 \%8F\&siteurl=pidruchniki. com \%2F19390825 \%2Fpravo \%2Ftlumachniy slovnik osnovnih _yuridichnih_ponyat_viznachen_terminiv\&ref=yandex.ru \%2F\&ss $=4388 \mathrm{j} 2862612 \mathrm{j} 11$

16. Redchenko, K. I. (2003). Stratehichnyi analiz v biznesi. Lviv: Novyy Svit-2000, 272.

17. Blakita, G. (2010). Metodologiya viboru vidu finansovoi strategii na pidpriemstvakh torgivli. Visnik KNTEU, 6, 48-60. Available at: http://visnik.knteu.kiev.ua/files/2010/06/6.pdf

18. Blank, I. O. (2003). Finansovo-ekonomichnyy mekhanizm funktsionuvannya vnutrishn'oyi torhivli. Visnyk Lvizskoyi komertsiynoyi akademiyi, 4, 59-65.

Chiz Ludmila, PhD, Associate Professor, Department of Economic and Finance, Odessa National Marine University, Ukraine, e-mail: chizj@rambler.ru,ORCID: http://orcid.org/0000-00028067-2346

Khotyeyeva Natalia, PhD, Associate Professor, Department of Economic and Finance, Odessa National Marine University, Ukraine, e-mail: otbrata1@gmail.com, ORCID: http://orcid.org/0000-00023858-6540

Zadorozna Natalia, Odessa National Marine University, Ukraine, e-mail:nataliiazdr@gmail.com, ORCID: http://orcid.org/0000-00021904-3102 